\title{
Losses caused by Groundnut ringspot tospovirus in peanut crop in the State of São Paulo
}

\section{Perdas ocasionadas por Groundnut ringspot tospovirus em plantios comerciais de amendoim no Estado de São Paulo}

\author{
Marcos Doniseti Michelotto ${ }^{*}$; Willians César Carrega ${ }^{2}$; Luis Eduardo Prado \\ Lamana $^{3}$; Tamiris Marion de Souza ${ }^{3}$; Ignácio José de Godoy ${ }^{4}$ Luciane de Nazaré \\ Almeida dos Reis ${ }^{5}$; André Luis Menezes Sales ${ }^{3}$; Rita de Cássia Pereira Carvalho ${ }^{6}$
}

\begin{abstract}
An increased incidence and severity of Orthotospovirus species has been observed in the peanut crop. The typical symptoms of the virus, usually known as ringspot in peanut and spotted wilt in other crops, include mosaic, chlorotic ring-shaped spots, necrosis, and plant stunting. This study aimed to verify the occurrence of this virus in peanut growing areas in the São Paulo State, Brazil, identify the predominant virus species, and determine losses resulting from the presence of this virus. Surveys were carried out in four peanut commercial areas sown in the municipalities of Santa Adélia and Cândido Rodrigues in the 2014/2015 season using the cultivar Granoleico. The following parameters were evaluated: plant stand, number of plants with symptoms, and severity of these symptoms through a scoring scale of visual symptoms. The results showed that the predominant virus species is Groundnut ringspot tospovirus (GRSV). Also, the lower the stand is, the higher the percentage of plants with virus symptoms. The mean incidence of GRSV in commercial peanut areas is $40 \%$, with mean losses estimated at $38 \%$ when GRSV is present and $64 \%$ when there is the presence of virus and reduction in plant density.
\end{abstract}

Key words: Arachis hypogaea L. Incidence. Severity. Tospovirus. Yield.

\section{Resumo}

É observado um aumento na incidência e severidade de espécies de Orthotospovirus na cultura do amendoim. Os sintomas típicos da virose genericamente conhecida por "vira-cabeça" em outras culturas e "mancha anelar em amendoim", incluem mosaico, manchas cloróticas em forma de anéis, necrose e nanismo das plantas. Diante disso, os objetivos deste trabalho foram realizar um levantamento da ocorrência dessa virose em áreas produtoras de amendoim em São Paulo, identificar a espécie viral predominante e determinar as perdas decorrentes da presença desse vírus. Para isto, levantamentos foram realizados em quatro áreas comerciais de amendoim, semeadas nos municípios de Santa Adélia e Cândido Rodrigues, na safra 2014/2015, utilizando a cultivar Granoleico. Determinou-se o estande de plantas, o número de plantas com sintomas e a intensidade destes sintomas através de uma escala de

\footnotetext{
Pesquisador, Agência Paulista de Tecnologia dos Agronegócios, APTA, Polo Regional Centro Norte, Pindorama, SP, Brasil. E-mail: michelotto@apta.sp.gov.br

2 Pesquisador, Universidade Estadual Paulista, UNESP, Jaboticabal, SP, Brasil. E-mail: willianscesar@hotmail.com

3 Bolsistas, APTA, Polo Regional Centro Norte, Pindorama, SP, Brasil. E-mail: luis_eduardo_lamana@hotmail.com; tamirismdsouza@hotmail.com; andre_sales@outlook.com

4 Pesquisador, Instituto Agronômico de Campinas, IAC, Campinas, SP, Brasil. E-mail: ijgodoy@iac.sp.gov.br

5 Discente de Doutorado, Universidade de Brasília, UNB, Brasília, DF, Brasil. E-mail: lucy_reis_@hotmail.com

6 Profa, UNB, Brasília, DF, Brasil. E-mail: rcpcarvalho@unb.br

"Author for correspondence
}

Received: Nov. 07, 2018 - Approved: May 20, 2019 
notas de sintomas visuais. Pelos resultados obtidos, constatou-se que a espécie de vírus predominante é Groundnut ringspot tospovirus (GRSV). Conclui-se que quanto menor o estande maior a percentagem de plantas com sintomas da virose. A incidência do GRSV nas áreas comerciais de amendoim é em média de $40 \%$ sendo as perdas médias estimadas em 38\% quando há a presença do GRSV e em $64 \%$, quando há a presença do vírus e a redução na densidade de plantas.

Palavras-chave: Arachis hypogaea L. Incidência. Produtividade. Severidade. Tospovirus.

\section{Introduction}

World peanut production in the last season was estimated at 44 million tons (USDA, 2018), being mainly used in the confectionery industry, as well as for oil extraction. The presence of virus species can cause large yield losses for the peanut crop. Species classified in the genus Orthotospovirus (MAES et al., 2019) are considered economically important, mainly due to its occurrence worldwide (PAPPU et al., 2009; TURINA et al., 2016). According to studies carried out by Riley et al. (2011) in the United States, Tomato spotted wilt tospovirus (TSWV) caused losses estimated at US\$ 1.4 billion over ten years. According to these authors, the mean annual losses caused by the presence of viruses in peanuts are US\$ 12.3 million.

In the last five years, peanut producers in the São Paulo State have reported an increase in the occurrence of plants with symptoms (chlorotic spots, ring-shaped, necrosis, and stunting) similar to a virus known as peanut ringspot, which is associated with yield losses. Considering the increased incidence of plants with these symptoms, Camelo-García et al. (2014) identified Groundnut ringspot tospovirus (GRSV) in peanut-producing crops in Itápolis. Godoy et al. (2017) also reported that peanut plants in the São Paulo State were infected, but in moderate intensity, by viruses of the Orthotospovirus group, especially TSWV and GRSV. Souza-Dias et al. (2005) and Andrade et al. (2005) reported the occurrence of Tomato chlorotic spot tospovirus (TCSV) in peanuts in the São Paulo State, while Reis et al. (2015) obtained complete sequences of GRSV genomes and Peanut mottle virus $(\mathrm{PeMoV})$ in samples from the São Paulo State.

In the genus Orthotospovirus, Culbreath et al. (2003) cited that the TSWV, TCSV, and GRSV species found in the United States occurred in the peanut crop, the first more frequently. In Brazil, a viral disease caused by TSWV was described by Costa (1941), but since then its incidence has always been low. In Brazil and probably in the world, there are still no scientific reports on peanut yield losses caused by GRSV. Currently, this species is distributed in the American, European, and African continents (EPPO, 2018) and according to Webster et al. (2015), GRSV has presented a growing incidence in Florida, USA, being considered an emerging threat to the production of many crops, including peanut (APPIAH et al., 2016).

TSWV, GRSV, and other species of the genus Orthotospovirus are transmitted exclusively by thrips (PAPPU et al., 2009; CULBREATH et al., 2003). In the United States, among the species of vector thrips are the Frankliniella fusca (Hinds) and Frankliniella occidentalis (Pergande) (CULBREATH et al., 2003). In Brazil, neither of these species is considered a pest in peanuts, only the species Enneothrips flavens Moulton (GALLO et al., 2002; MICHELOTTO et al., 2013; MICHELOTTO et al., 2017). However, in surveys conducted together with virus identification, a high incidence of Frankliniella schultzei Trybon was observed in peanut flowers (CAMELO-GARCIA et al., 2014). This species has also been reported as one of the main disease vectors in peanut areas in Argentina (BREUIL et al., 2008). Also, this species of thrips is the main vector of TCSV, TSWV, and GRSV (NAGATA et al., 2004; NAGATA et al., 2007).

Therefore, this study hypothesized that the initial occurrence of GRSV observed in peanut production areas can cause severe damage to plants and reduce crop yield. The necrosis caused by it can compromise the ability to intercept radiation, photosynthesis, and transpiration and, consequently, cause reductions in 
peanut quality and productivity, leading producers to serious financial losses. Several strategies have been adopted to reduce the damage caused by the disease, such as the use of resistant cultivars, choice of the sowing season, lower spacing, and direct sowing (CULBREATH et al., 2003). For Brazilian conditions, there is no information on the behavior of local cultivars in relation to the disease, nor on the ideal sowing time. However, a higher plant density is a possible strategy to be used under Brazilian conditions. Therefore, this study aimed to determine the losses caused by Groundnut ringspot tospovirus in commercial peanut growing areas in the São Paulo State and correlate them with plant stand.

\section{Material and Methods}

Surveys were carried out in four commercial areas of the peanut cultivar Granoleico located in
Cândido Rodrigues (areas A, B, and C) and Santa Adélia (area D), São Paulo State, Brazil, in the 2014/2015 season. Twenty plant rows in sequence were delimited at each site to evaluate disease occurrence, with five sampling units of four meters each, totaling 100 sampling units.

The following parameters were evaluated at each sampling unit: number of plants per meter (stand), number of plants with symptoms of the disease, and a scoring scale of visual symptoms of the disease. The scale used to evaluate the severity of symptoms of TSWV was proposed by Lyerly et al. (2002) and Nascimento et al. (2006) and adapted for GRSV, where 1 was assigned for plants without symptoms, 2 for leaves with symptoms of yellowing, mosaic, and/or chlorotic spots, 3 for plants with symptoms of yellowing, mosaic and/or chlorotic spots, and height reduction), and 4 for chlorotic plants and stunting (Figure 1).

Figure 1. Scoring scale of GRSV symptoms in peanut plants. Score 1: plant without symptoms; Score 2: leaves with symptoms (circle) of yellowing, mosaic, and/or chlorotic spots; Score 3: plant with symptoms of yellowing, mosaic and/or chlorotic spots, and height reduction); Score 4: chlorotic plants and stunting.
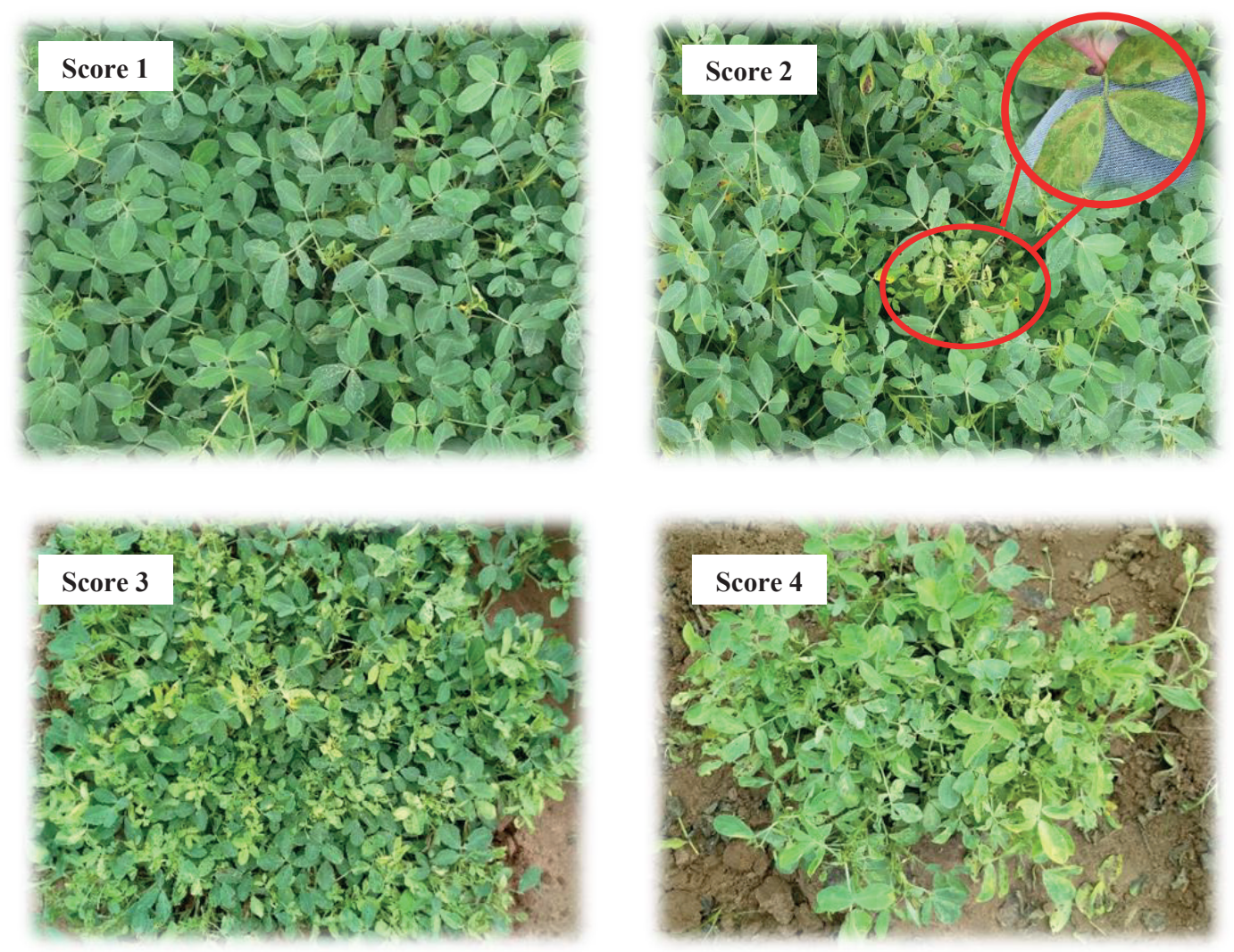

Semina: Ciências Agrárias, Londrina, v. 40, n. 6, suplemento 3, p. 3429-3442, 2019 
From the stand and percentage of plants with virus, sampling units were classified as 1) stand with failures and with a high virus incidence (WF+WV); 2) with failures and no virus (WF+NV); 3) no failures and with virus (NF+WV) and; 4) no failures and no virus $(\mathrm{NF}+\mathrm{NV})$, being the percentage of plants with virus and stand analyzed again.

Pod yield $\left(\mathrm{kg} \mathrm{ha}^{-1}\right)$ was also evaluated by harvesting four sampling units from each classification, aiming to correlate the stand, disease occurrence, and effects on yield.

Also, the number and weight of pods ( $g$ ) were evaluated for each scoring scale of visual symptoms of the disease in 10 individual plants in areas $\mathrm{A}$ and $\mathrm{D}$.

Plants exhibiting chlorotic ring-shaped spots and necrosis were collected, packed in Styrofoam boxes with ice, and sent to the Laboratory of Plant Virology at the University of Brasília (LVV-Fito $\mathrm{UnB}$ ) to identify the virus species.

The total RNA extraction was performed using the Hot-Phenol protocol according to Verwoerd et al. (1989). The cDNA for the $\mathrm{N}$ gene (Tospovirus $\mathrm{S}$ segment) was synthesized using reverse transcriptase MMLV (Invitrogen) according to the manufacturer's manual. The cDNA was synthesized using $1 \mu \mathrm{L}$ reverse primer $(10 \mathrm{pmoles} / \mathrm{uL}), 10 \mathrm{uL}$ total RNA (1-2 ug), $1 \mu \mathrm{L} \mathrm{dNTP}(10 \mathrm{mM})$, and incubation at 70 ${ }^{\circ} \mathrm{C}$ for 5 minutes. Then, $4 \mu \mathrm{L}$ (5X MMLV) enzyme buffer, $1 \mu \mathrm{LDTT}(0.1 \mathrm{M}), 1 \mathrm{uLRNase}$ Out (40 U/uL), $1 \mu \mathrm{L} \mathrm{H}_{2} \mathrm{O}$ milliQ, and $1 \mu \mathrm{L}$ MMLV-RT (Invitrogen) (200 U/uL) were added. Incubation was carried out at $37{ }^{\circ} \mathrm{C}$ for $60 \mathrm{~min}$, followed by incubation at $70{ }^{\circ} \mathrm{C}$ for 15 minutes. In PCR, amplification was carried out with Platinum Taq DNA Polymerase
Invitrogen ${ }^{\mathrm{TM}}(5 \mathrm{U} / \mathrm{uL})$ and the pair of primers: $5^{\prime}$ TATGTCTAAGGTCAAGCTCACAAAAGAAAA CAT 3' and ReV:5'CTCATGCAACACCAGCAATC TTGGCTTCTTT 3. PCR conditions were 35 cycles of $94{ }^{\circ} \mathrm{C}$ per 30 seconds, denaturation at $94{ }^{\circ} \mathrm{C}$ for 30 seconds, annealing at $56{ }^{\circ} \mathrm{C}$ for 30 seconds, extension at $72{ }^{\circ} \mathrm{C}$ for 1 minute, and a final extension at $72{ }^{\circ} \mathrm{C}$ for 10 minutes. The PCR product was loaded onto $1 \%$ agarose gel and electrophoresed with $0.5 \mathrm{X} \mathrm{TBE}$ and stained with ethidium bromide. The purified amplicons were sent to Sanger sequencing (MACROGEN). The obtained sequences were aligned with MAFFT using Geneious 7.1 (KEARSE et al., 2012) and compared to sequences available on BLAST (http://blast.ncbi.nlm.nih.gov/).

\section{Results}

All evaluated areas presented a lower stand when compared to the recommended for cultivars with a runner growth habit, which has values from 12 to 14 plants per meter (GODOY et al., 2014). In addition, the results of molecular analyses identified only the presence of GRSV in all samples from the evaluated sites.

Areas A, B, and C showed 90, 95, and 92\% of sampled points below 8.6 plants $\mathrm{m}^{-1}$, respectively (Figure 2A, B, and C). Area D showed $61 \%$ of points with a stand below 8.6 plants $\mathrm{m}^{-1}$ (Figure 2D). For this reason, the data were analyzed and interpreted taking into account these variations and the fact that all the sampling units had a below-normal stand. All the parameters evaluated as a function of stand and elaborated classes presented a significant difference between the two evaluated sites (Table 1). 
Figure 2. Number of sampling units as a function of the stand (plants $\mathrm{m}^{-1}$ ) of 'Granoleico' peanuts obtained in commercial areas evaluated in Cândido Rodrigues (areas A, B, and C) and Santa Adélia (area D), São Paulo State, in the $2014 / 15$ season.
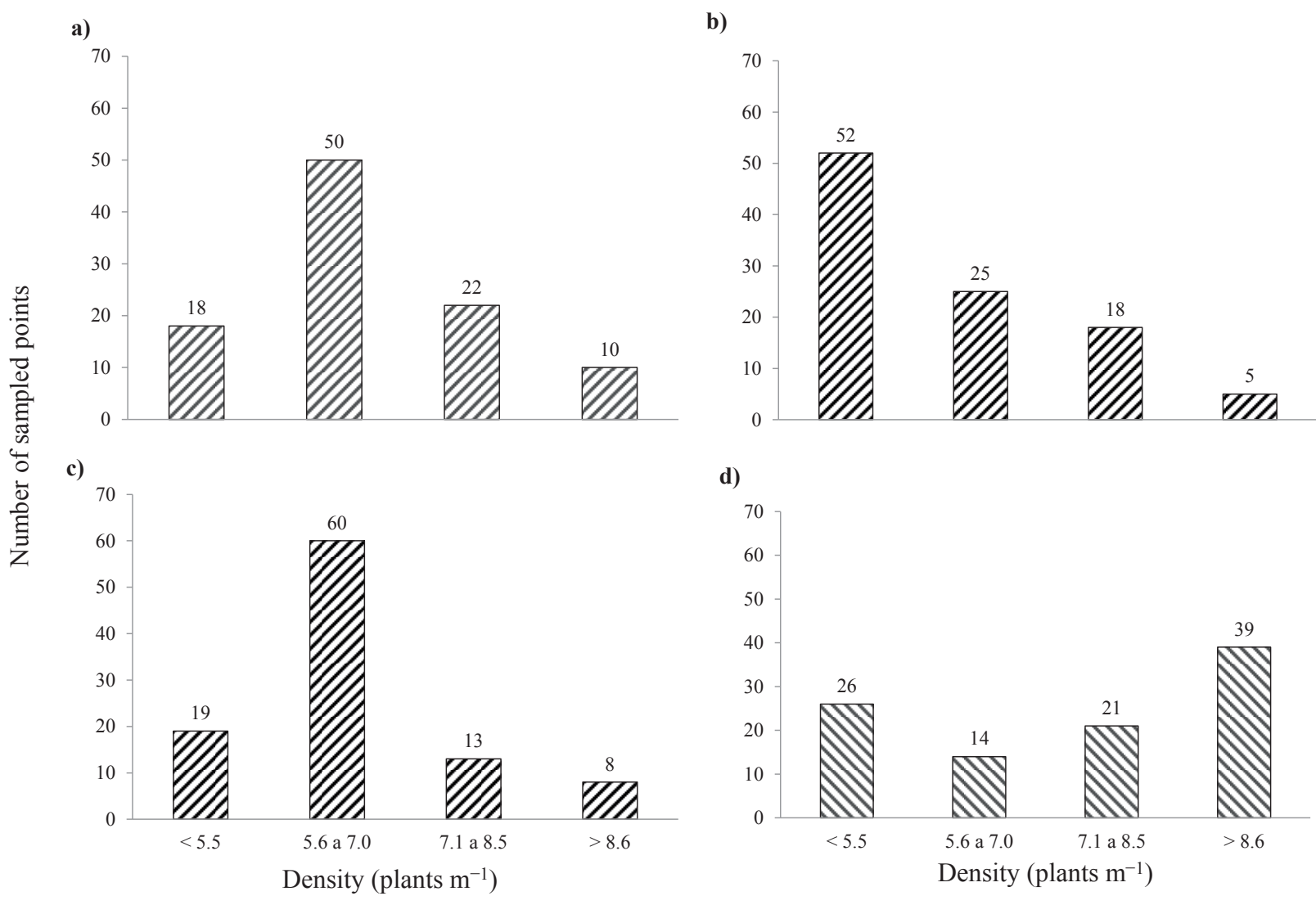

Table 1. Parameters evaluated by F-test in peanut 'Granoleico' plants in commercial areas of Cândido Rodrigues (areas A, B, and C) and Santa Adélia (area D), São Paulo State, in the 2014/15 season.

\begin{tabular}{|c|c|c|c|c|c|}
\hline & \multirow{3}{*}{ Evaluated parameter } & \multicolumn{4}{|c|}{ F-test } \\
\hline & & \multicolumn{3}{|c|}{ Cândido Rodrigues } & \multirow{2}{*}{$\frac{\text { Santa Adélia }}{\text { Area D }}$} \\
\hline & & Area A & Area B & Area $\mathrm{C}$ & \\
\hline 1. & $\begin{array}{l}\text { Percentage of plants with virus as a function of plant } \\
\text { stand at the evaluated points (Figure 2) }\end{array}$ & $3.84 *$ & $3.89 *$ & $9.58 * *$ & $33.05 * *$ \\
\hline 2. & $\begin{array}{l}\text { Number of plants per meter as a function of the evalu- } \\
\text { ated classes (Figures } 3 \text { and } 4 \text { ) }\end{array}$ & $69.96^{* *}$ & $44.17 * *$ & $31.54^{* *}$ & $38.50 * *$ \\
\hline 3. & $\begin{array}{l}\text { Percentage of plants with virus as a function of the } \\
\text { evaluated classes (Figure } 3 \text { ) }\end{array}$ & $21.09^{* *}$ & $140.11^{* *}$ & $37.50^{* *}$ & $87.61 * *$ \\
\hline 4. & $\begin{array}{l}\text { Score of visual symptoms of plants with virus as a } \\
\text { function of the evaluated classes (Figure } 4 \text { ) }\end{array}$ & $26.67^{* *}$ & $110.59 * *$ & $8.63 * *$ & $54.08 * *$ \\
\hline 5. & $\begin{array}{l}\text { Yield }\left(\mathrm{kg} \mathrm{ha}^{-1}\right) \text { as a function of the evaluated classes } \\
\text { (Figure 5) }\end{array}$ & $8.08 * *$ & $21.63 * *$ & $4.03 *$ & $13.57 * *$ \\
\hline 6. & Number of viable pods & $35.53^{* *}$ & ----- & ----- & $14.87 * *$ \\
\hline & Weight of viable pods & $49.90^{* *}$ & ----- & ---- & $37.10^{* *}$ \\
\hline
\end{tabular}

*,**: Significant at 1 and 5\%, respectively. -----: not evaluated. 
An increase in stand reduced the percentage of plants with symptoms when the percentage of plants with virus symptoms was analyzed as a function of plant stand per meter (Figure 3). In areas A, B, and $\mathrm{C}$, sites with major plant failures, the percentage of plants with virus symptoms varied from 56 to $68.2 \%$ when plant density in the row was lower than 5.5 plants $\mathrm{m}^{-1}$ (Figure 3A, B, and C). For this same density in area $\mathrm{D}$, the percentage of plants with virus symptoms was $39.2 \%$ (Figure 3D).

Figure 3. Percentage of plants with symptoms of GRSV in the stand (plants $\mathrm{m}^{-1}$ ) of 'Granoleico' peanut plants in production areas located in Cândido Rodrigues (areas A, B, and C) and Santa Adélia (area D), São Paulo State, in the 2014/15 season.

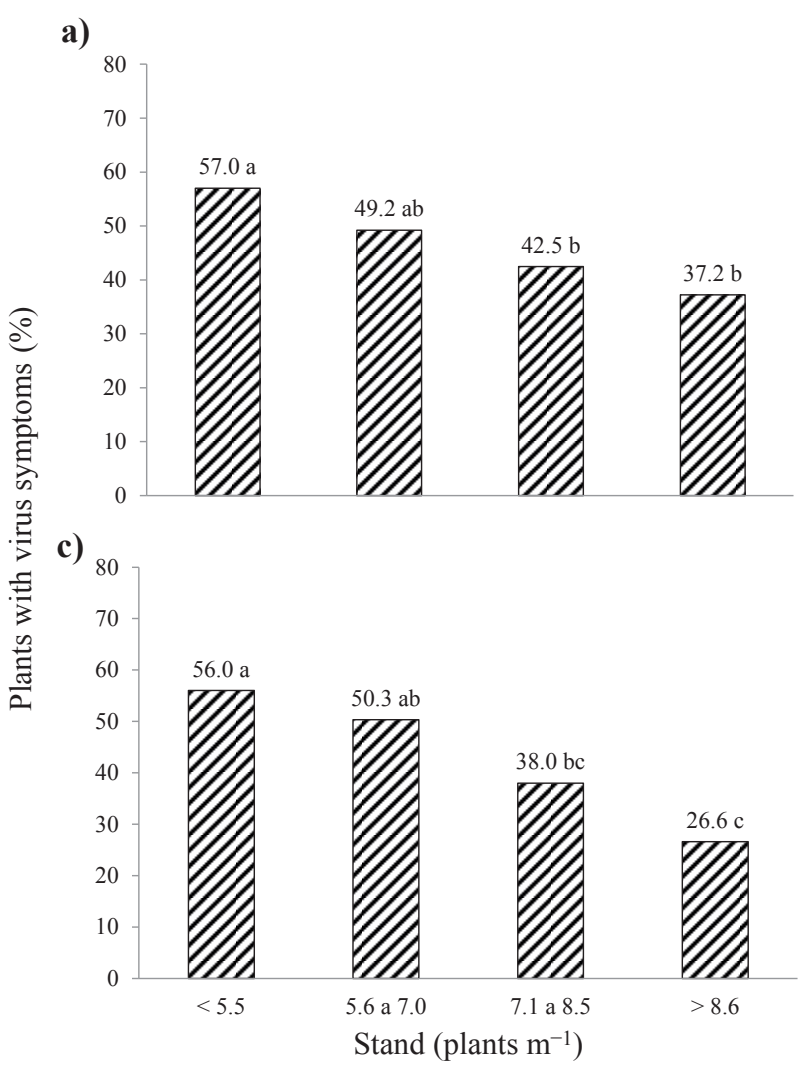

A high percentage of sampling units in the $\mathrm{WF}+\mathrm{WV}$ class was observed in the classification of sampling units according to incidence and stand, i.e., a high failure and many plants with virus led to a percentage of plants with symptoms of $78.0 \%$ in area C to $92.5 \%$ in area B (Figure $4 \mathrm{~A}, \mathrm{~B}$, and C). In area $\mathrm{D}$ (Santa Adélia), where a lower incidence of plants with disease symptoms was observed when compared to the areas of Cândido Rodrigues, virus symptoms were higher than $50 \%$ in the lowest density (3.4 plants $\mathrm{m}^{-1}$ ) (Figure 4D). b)
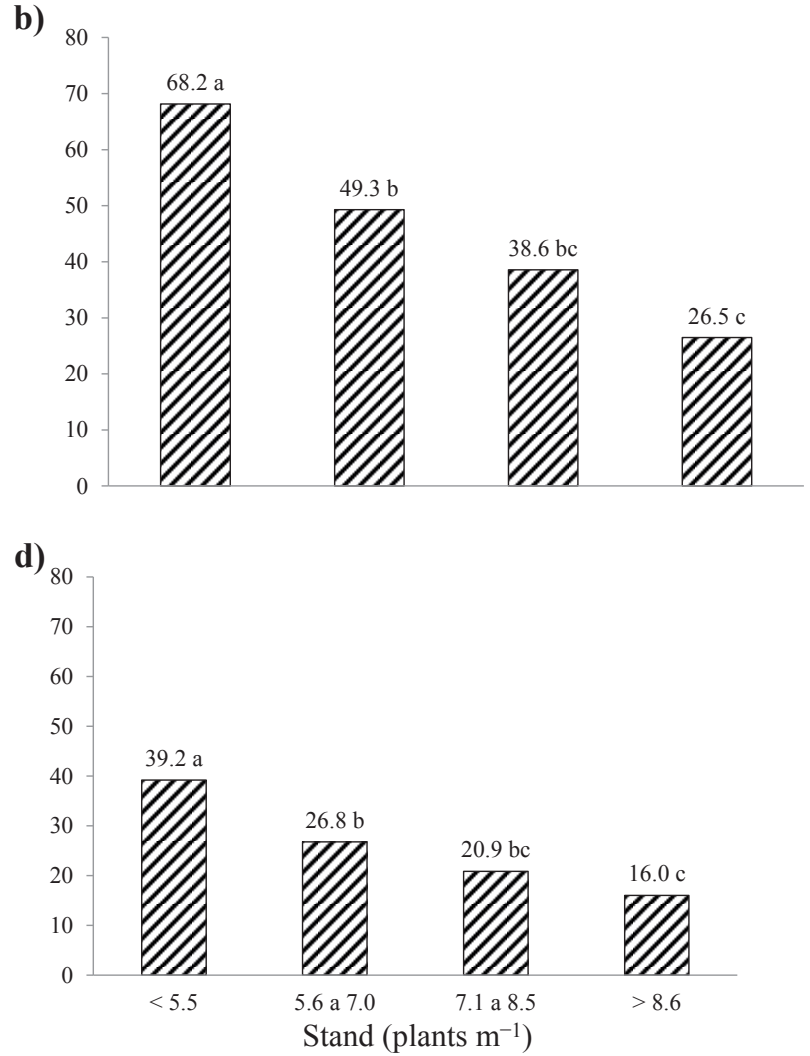

Considering the classification of lower impact $(\mathrm{NF}+\mathrm{NV})$, i.e., without failure, without virus, and a good stand for that condition, 25.4, 20.1, 21.6, and $8.6 \%$ of plants with virus symptoms were observed respectively for areas A, B, C (Cândido Rodrigues), and D (Santa Adélia) (Figure 4).

The mean disease reductions due to the increased density of plants $\mathrm{m}^{-1}$ in the $\mathrm{NF}+\mathrm{WV}$ and $\mathrm{NF}+\mathrm{NV}$ classifications were estimated at $54 \%$. These reductions were more pronounced in the $\mathrm{WF}+\mathrm{WV}$ classifications when compared to $\mathrm{NF}+\mathrm{NV}$, with mean reductions of $75 \%$ (Figure 4 ). 
Infection intensity analyzed through the scoring scale proposed in Figure 1 showed the same pattern for the percentage of plants infected with the disease in both sites, i.e., the lower the stand is, the higher the score of disease symptoms, with score values ranging from 1.00 and 2.01 in stands of 3.4 and 4.6 plants $\mathrm{m}^{-1}$ (Figure 5). The scores of GRSV symptoms were, on average, $69 \%$ lower in the $\mathrm{NF}+\mathrm{NV}$ classification when compared to $\mathrm{NF}+\mathrm{WV}$, and even lower (84\%) in the comparison between $\mathrm{NF}+\mathrm{NV}$ and $\mathrm{WF}+\mathrm{WV}$ (Figure 5), showing that the presence of GRSV in peanut areas can be highly detrimental under inadequate management.

Figure 4. Percentage of plants with GRSV symptoms according to the classification: WF $+\mathrm{WV}=$ stand with failures and with a high virus incidence; $\mathrm{WF}+\mathrm{NV}=$ with failures and no virus; $\mathrm{NF}+\mathrm{WV}=$ no failures and with virus; and $\mathrm{NF}+\mathrm{NV}=$ no failures and no virus, obtained in commercial areas evaluated in Cândido Rodrigues (areas A, B, and C) and Santa Adélia (area D), São Paulo State, in the 2014/15 season.

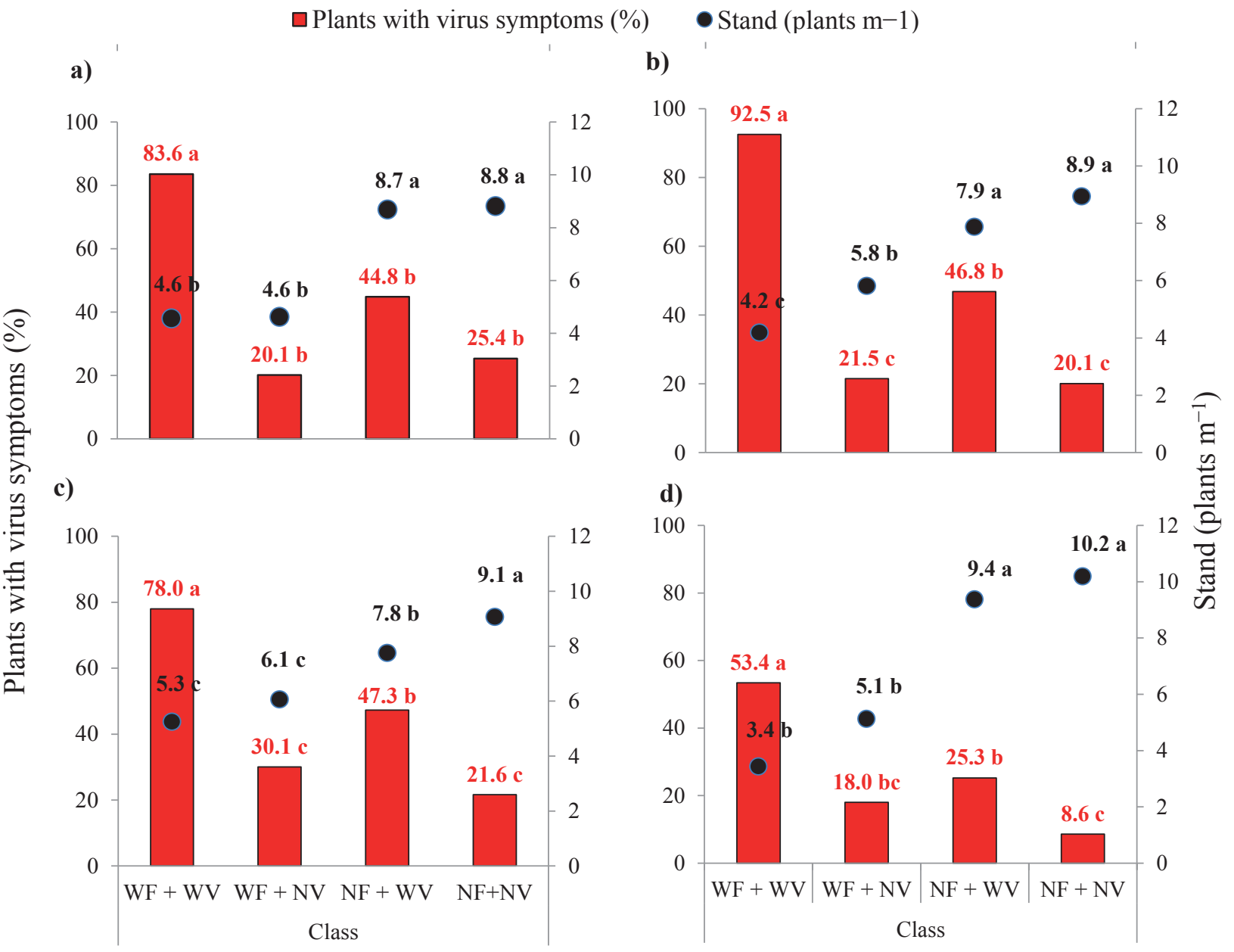

Figures 6, 7, and 8 show the number and weight of peanut pods as a function of the scores of GRSV symptoms. In this sense, a reduction in the two evaluated parameters was observed from score 2 . The reduction in the number of pods in the areas of Cândido Rodrigues (Figure 6) and Santa Adélia (Figure 7) was 80 and $73 \%$, respectively, when score 1 (without virus) was compared to score 4 (plants with a high disease incidence). Similar behavior was observed when comparing these same scores 
with pod weight at these sites, with reductions of 97 and 96\%, respectively (Figures 6 and 7).

The low stand and high virus incidence influenced yield. In this sense, the highest yields were observed in the classification without failures, with low virus and more plants (stand) for both sites. In the $\mathrm{WF}+\mathrm{WV}$ classification, yield ranged from 1,069.4 to $1,285.0 \mathrm{~kg} \mathrm{ha}^{-1}$ among the study areas under the lowest plant density. The NF+NV classification showed a mean yield of the experimental areas of 3,307.1 $\mathrm{kg} \mathrm{ha}^{-1}$ (Figure 9), with area B presenting the highest productive potential $\left(3,840.3 \mathrm{~kg} \mathrm{ha}^{-1}\right)$.
Considering the mean of all areas in the comparison of yield for the NF+NV (no failure and low virus incidence) and NF+WV (no failure and with virus) classifications, the yield was reduced by $38 \%$, with losses reaching $1,241.25 \mathrm{~kg} \mathrm{ha}^{-1}$. Under more extreme conditions, the WF+WV (with stand failure and with a high virus incidence) classification, the reduction was more pronounced (64\%) when compared to NF+NV, with yields losses estimated at 2,126.5 $\mathrm{kg} \mathrm{ha}^{-1}$ (Figure 9). Thus, the need to increase plant stand to suppress the damages caused by the GRSV vector insects is evident.

Figure 5. Scores of GRSV symptoms according to the classification: WF+WV = stand with failures and with a high virus incidence; $\mathrm{WF}+\mathrm{NV}=$ with failures and no virus; $\mathrm{NF}+\mathrm{WV}=$ no failures and with virus; and $\mathrm{NF}+\mathrm{NV}=$ no failures and no virus, obtained in commercial areas evaluated in Cândido Rodrigues (areas A, B, and C) and Santa Adélia (area D), São Paulo State, in the 2014/15 season.

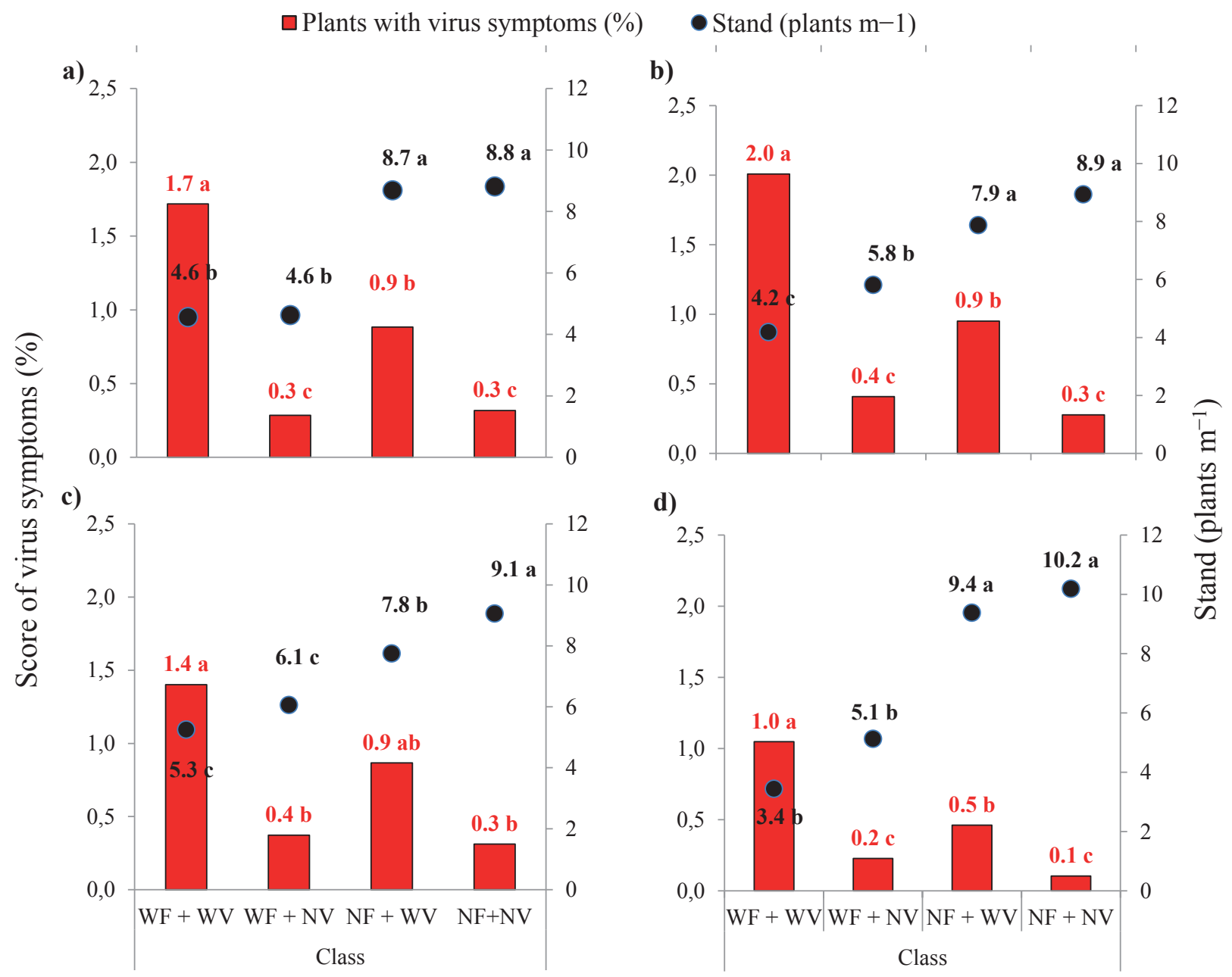


Figure 6. Number and weight of peanut pods as a function of scores of GRSV symptoms scores in the area A of Cândido Rodrigues.
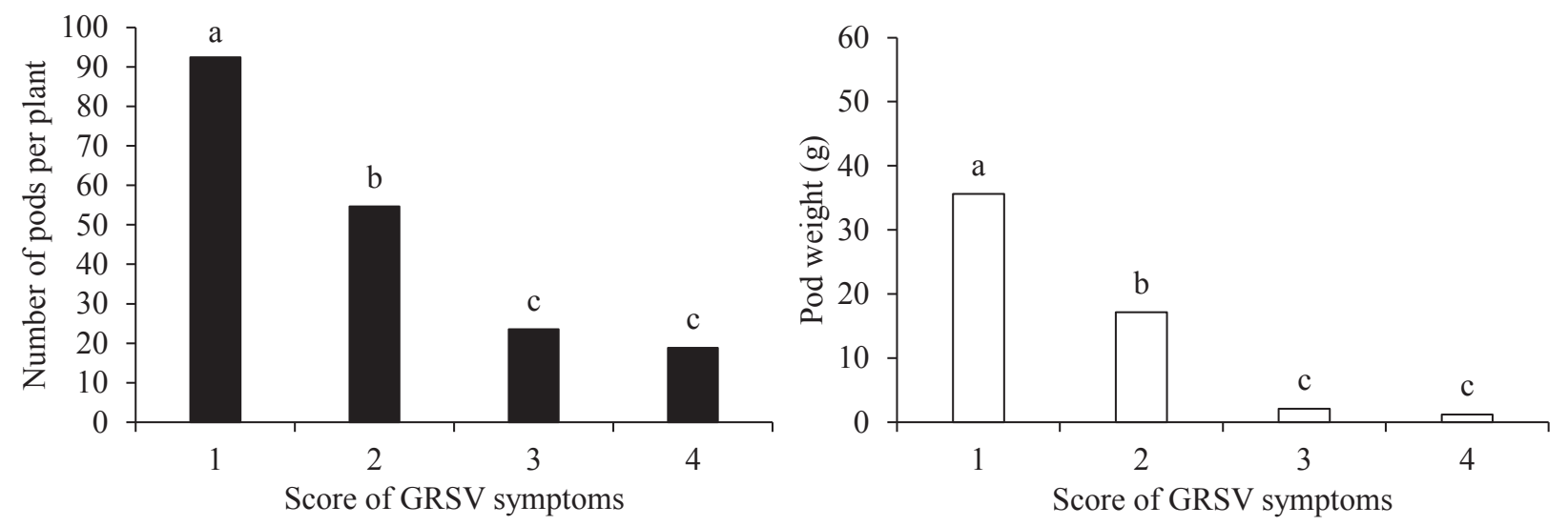

Figure 7. Number and weight of peanut pods as a function of scores of GRSV symptoms scores in the area of Santa Adélia.
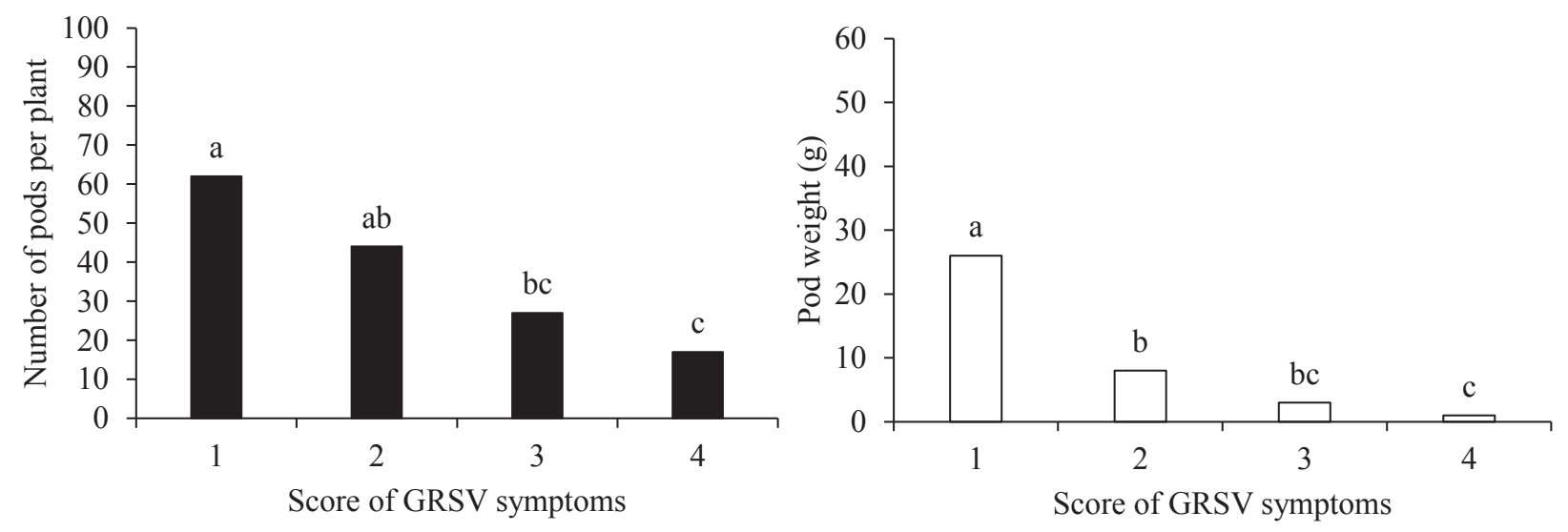

Figure 8. Peanut plants with a reduced number of pods associated with a scoring scale used to evaluate the symptoms caused by GRSV.

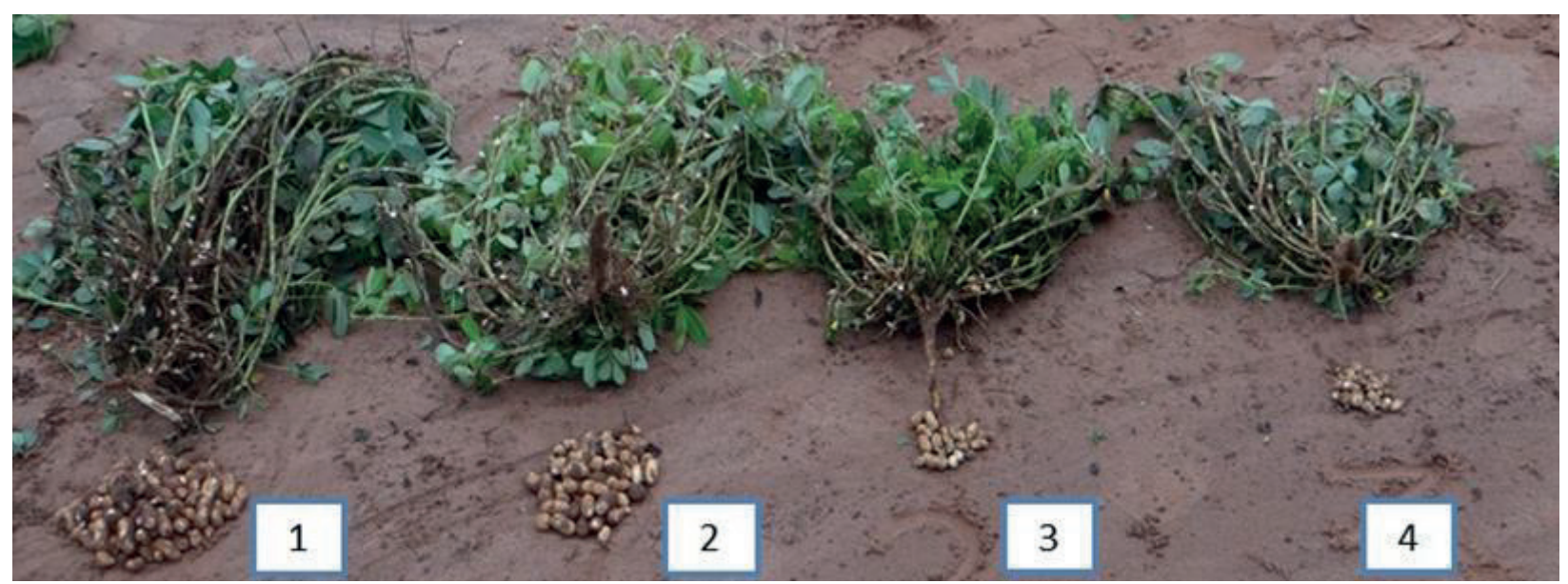


Figure 9. Productivity $\left(\mathrm{kg} \mathrm{ha}^{-1}\right)$ according to the classification: $\mathrm{WF}+\mathrm{WV}=$ stand with failures and with a high virus incidence; $\mathrm{WF}+\mathrm{NV}=$ with failures and no virus; $\mathrm{NF}+\mathrm{WV}=$ no failures and with virus; and $\mathrm{NF}+\mathrm{NV}=$ no failures and no virus, obtained in commercial areas evaluated in Cândido Rodrigues (areas A, B, and C) and Santa Adélia (area D), São Paulo State, in the 2014/15 season.

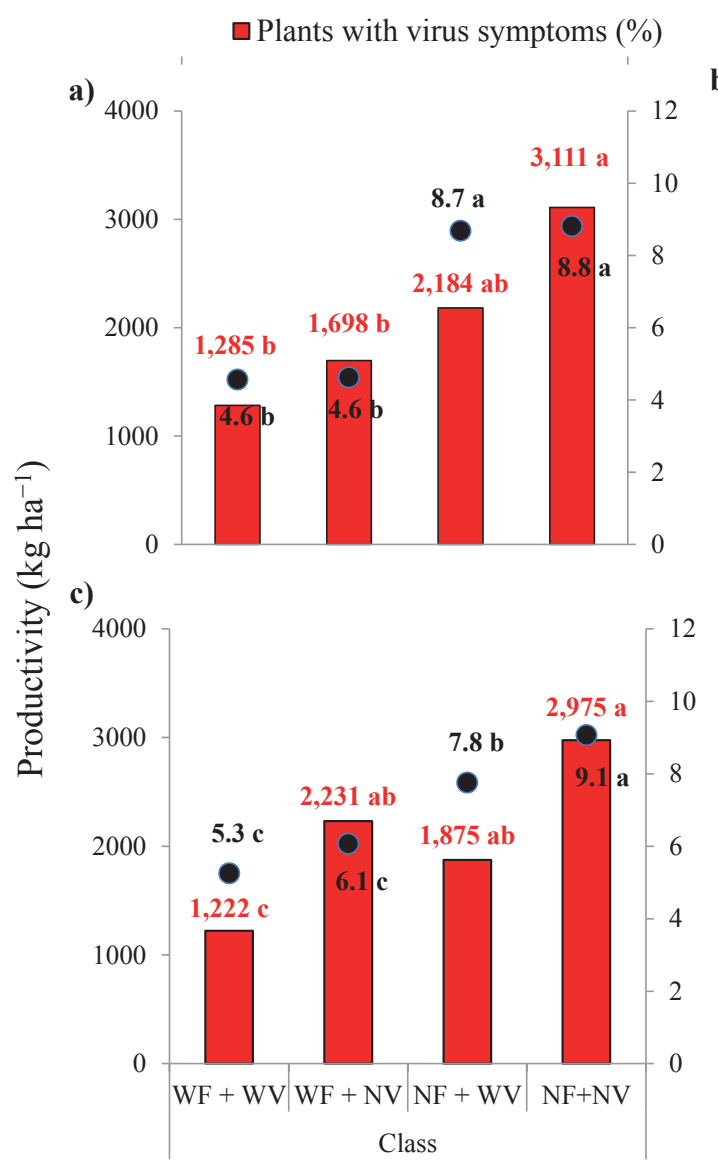

\section{Discussion}

This study showed that GRSV has occurred in peanut-growing areas of the São Paulo State. In addition to the areas of Itápolis, as reported initially by Camelo-García et al. (2014), the presence of this virus was also detected in Cândido Rodrigues and Santa Adélia. According to the survey, the occurrence of GRSV in these areas is of great concern to producers and agricultural sector.

The occurrence of TSWV and Groundnut bud necrosis tospovirus (GBNV) in the crop, especially TSWV in the United States, has been reported for many years causing reductions ranging from 70 to $95 \%$ (SINGH; SRIVATAVA, 1995; BLACK et al., 1986; LOWRY et al., 1993). However, losses
- Stand (plants m-1)

b)

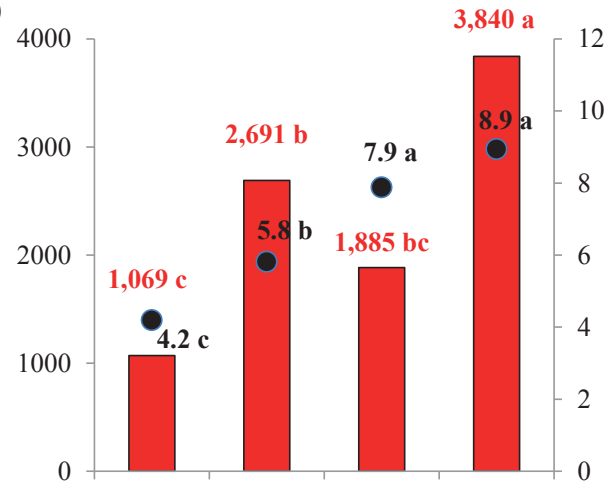

d)

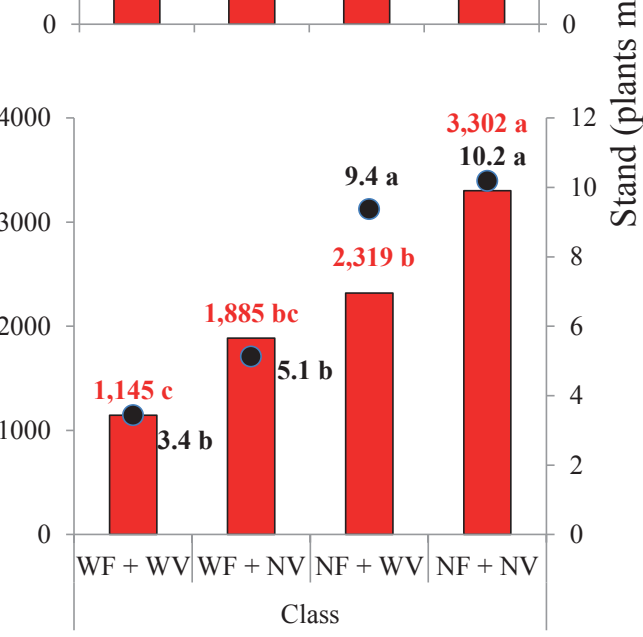

resulting from GRSV in peanut-growing areas in Brazil and the world are little known. In this study, the yield of the Granoleico cultivar was reduced by $38 \%$ when there was no control of this disease and could be higher than $64 \%$ under the presence of the virus and in areas with lower plant density (Figure 9).

Because there is still no effective chemical control for Orthotospovirus spread need to be minimized. For this, it is necessary to control vector insects in the production field (RELEVANTE et al., 2012). This control has been carried out chemically, but, given the high incidence of these insects in agricultural areas, applications are not $100 \%$ effective. The incidence of these insects is a 
constant challenge for producers since applications are carried out weekly throughout the growing cycle. Also, another factor that may be harmful in the future is the possibility of vector populations resistant to insecticides, which could further worsen problems with viruses. Thus, good practices of crop management are sustainable alternatives to face emerging problems caused by Orthotospovirus species, especially TSWV and GRSV.

Studies observing virus-resistant cultivars have been developed by IAC and APTA in partnership with the University of Georgia, Tifton, USA. Researchers have tested Brazilian cultivars in comparison to American ones under high severity levels of TSWV. In these studies, the cultivar IAC OL5 showed a moderate resistance, while the cultivars Granoleico, IAC OL3, and IAC 886 were susceptible to the virus (GODOY et al., 2017).

In this study, besides confirming the presence of the virus, damages were evidence, and a visual scale of GRSV symptoms was developed (Figure 1). Based on this scale, the increased density $(>8.6$ plants $\mathrm{m}^{-1}$ ) led to a reduction in the percentage of plants with GRSV symptoms, being 52\% lower in relation to a density lower than 5.5 plants $\mathrm{m}^{-1}$ (Figure 3). According to Culbreath et al. (2003), the increased stand did not reduce the number of plants infected by TSWV but reduced the percentage of infected plants in the area. An increase in plant density ensures a higher coverage, diluting the damage caused by insect vectors and hence a reduction in the virus (CULBREATH et al., 2012; CULBREATH et al., 2013), corroborating the results observed in this study for GRSV. Moreover, Hurt et al. (2006) also observed a similar behavior (lower TSWV incidence) when peanut plants were under a higher density.

Thus there is a lack of information on this virus under Brazilian conditions, thus demonstrating the need for new researches to elucidate several existing doubts, such as whether the only vector is F. shultzei or whether E. flavens, the main insect- pest of the crop, can also be a vector of this disease. As well as which fungicides can be used to control the virus, development of epidemiological studies to understand how virus spreads, the physiological damages caused in plants, development of resistant cultivars to these viruses, and an improved management by testing densities and pattern of sowing rows (single and double rows). Studies on these subjects should be prioritized to minimize the impacts these viruses may have on the peanut crop.

\section{Conclusions}

Increasing plant density reduced the percentage of plants with symptoms and damage caused by GRSV, possibly being a viable alternative to crop management.

The mean incidence of GRSV in commercial peanut areas is $40 \%$, with mean losses estimated at $38 \%$ when GRSV is present and $64 \%$ under the presence of the virus and reduction in plant density.

\section{Acknowledgments}

To CNPq, for the granting the productivity fellowship in Technological Development and Innovative Extension to the first author; to the collaboration of COPLANA technicians; and to farmers, for providing the study areas. We also thank Professor Renato de Oliveira Resende (Department of Cell Biology, University of Brasília), for providing the $\mathrm{N}$ primer used in this study.

\section{References}

ANDRADE, G. P.; PIO-RIBEIRO, G.; SOUZA-DIAS, J. A. C.; COLARICCIO, A.; GODOY, I. J.; DOMINGOS, C. A.; CHAGAS, C. M. Tomato chlorotic spot virus TCSV infectando amendoim em áreas comerciais em São Paulo: levantamento e caracterização de isolados. In: CONGRESSO BRASILEIRO DE FITOPATOLOGIA, 38., 2005, Brasília. Anais... Brasília: Sociedade Brasileira de Fitopatologia, 2005. p. S.192. 
APPIAH, A. S.; OFFEI, S. K.; TEGG, R. S.; Wilson, C. $\mathrm{R}$. Varietal response to groundnut rosette disease and the first report of Groundnut ringspot virus in Ghana. Plant Disease, v. 100, n. 5, p. 946-952, 2016. DOI: 10.1094/ PDIS-07-15-0838-RE

BLACK, M. C.; LUMMUS, P. F.; SMITH, D. H.; DEMSKI, J. W. An epidemic of spotted wilt disease in South Texas peanuts in 1985. In Proceeding American Peanut Research \& Education Society, v. 18, p. 66, 1986. Abstract.

CAMELO-GARCÍA， V. M.; LIMA， É. F. B.; MANSILLA-CÓRDOVA, P. J.; REZENDE, J. A. M.; KITAJIMA, E. W.; BARRETO, M. Occurrence of Groundnut ringspot virus on Brazilian peanut crops. Journal of General Plant Pathology, v. 80, n. 3, p. 282286, 2014. DOI: 10.1007/s10327-014-0518-2

COSTA, A. S. Uma moléstia de vírus de amendoim (Arachis hypogaea L.) A mancha anular. Biológico, v. 7, n. 1, p. 249-251, 1941.

CULBREATH, A. K.; TUBBS, R. S.; TILLMAN, B. L.; BEASLEY, J. P.; BRANCH, W. D.; HOLBROOK, C. C.; SMITH, A. R.; SMITH, N. B. Effects of seeding rates and cultivar on tomato spotted wilt of peanut. Crop Protection, v. 53, n. 1, p. 118-124, 2013. DOI: 10.1016/j. cropro.2013.07.001

CULBREATH, A. K.; BRANCH, W. D.; BEASLEY JR., J. P.; TUBBS, R. S.; HOLBROOK, C. C. Peanut genotype and seeding rate effects of spotted wilt. Plant Health Progress, v. 13, n. 1, p. 23, 2012. DOI: 10.1094/ PHP-2012-0227-03-RS

CULBREATH, A. K.; TODD, J. W.; BROWN, S. L. Epidemiology and management of Tomato spotted wilt in peanut. Annual Review of Phytopathology, v. 41 , n. 1 , p. $53-75,2003$. DOI: 10.1146/annurev. phyto.41.052002.095522

BREUIL, S. de.; NIEVAS, M. S.; GIOLITTI, F. J.; GIORDA, L. M.; LENARDON, S. L. Occurrence, prevalence, and distribution of viruses infecting peanut in Argentina. Plant Disease, v. 92, n. 8, p. 1237-1240, 2008. DOI: $10.1094 /$ PDIS-92-8-1237

EUROPEAN AND MEDITERRANEAM PLANT PROTECTION ORGANIZATION - EPPO. Groundnut ringspot orthotospovirus. 2018. Available at: http://www. eppo.int. Access at: 02 jan. 2018.

GALLO, D.; NAKANO, O.; SILVEIRA NETO, S.; CARVALHO, R. P. L.; BATISTA, G. C.; BERTI FILHO, E.; PARRA, J. R. P.; ZUCCHI, R. A.; ALVES, S. B.; VENDRAMIN, J. D.; MARCHINI, L. C.; LOPES, J. R. S.; OMOTO, C. Entomologia Agrícola. Piracicaba: FEALQ, 2002. $920 \mathrm{p}$.
GODOY, I. J. D.; SANTOS, J. F. D.; MICHELOTTO, M. D.; MORAES, A. R. A. D.; BOLONHEZI, D.; FREITAS, R. S. D.; CARVALHO, C. R. L.; FINOTO, E. L.; MARTINS, A. L. M. IAC OL 5-New high oleic runner peanut cultivar. Crop Breeding and Applied Biotechnology, v. 17, n. 3, p. 295-298, 2017. DOI: $10.1590 / 1984-70332017 \mathrm{v} 17 \mathrm{n} 3 \mathrm{c} 45$

GODOY, I. J.; BOLONHEZI, D.; MICHELOTTO, M. D.; FINOTO, E. L.; KASAI, F. S.; FREITAS, R. S. Amendoim Arachis hypogaea L. In: AGUIAR, A. T. E.; GONÇALVES, C.; PATERNIANI, M. E. A. G. Z.; TUCCI, M. L. S.; CASTRO, C. E. F. (Ed.). Instruções agrícolas para as principais culturas econômicas. 7. ed. Campinas: Instituto Agronômico, 2014. p. 22-27. (Boletim, 200).

HURT, C. A.; BRANDENBURG, R. L.; JORDAN, D. L.; ROYALS, B. M.; JOHNSON, P. D. Interactions of tillage with management practices designed to minimize tomato spotted wilt of peanut (Arachis hypogaea L.). Peanut Science, v. 33, n. 2, p. 83-89, 2006. DOI: 10.3146/0095-3679(2006)33[83:IOTWMP]2.0.CO;2

KEARSE, M.; MOIR, R.; WILSON, A.; STONESHAVAS, S.; CHEUNG, M.; STURROCK, S.; BUXTON, S.; COOPER, A.; MARKOWITZ, S.; DURAN, C.; THIERER, T.; ASHTON, B.; MEINTJES, P.; DRUMMOND, A. Geneious Basic: an integrated and extendable desktop software platform for the organization and analysis of sequence data. Bioinformatics, v. 28, n. 12, p. 1647-1649, 2012. DOI: 10.1093/bioinformatics/ bts 199

LYERLY, J. H.; STALKER, H. T.; MOYER, J. W.; HOFFMAN, K. Evaluation of Arachis species for resistance to tomato spotted wilt virus. Peanut Science, v. 29 , n. 2, p.79-84, 2002. DOI: 10.3146/pnut.29.2.0001

LOWRY, V. K.; SMITH JR., J. W.; MITCHELL, F. L. Primary spread of Tomato spotted wilt virus on South Texas peanut. Proceeding American Peanut Research \& Education Society, v. 25, n. 1, p. 64, 1993.

MAES, P.; ADKINS, S.; ALKHOVSKY, S. V.; AVŠIČ-ŽUPANC, T.; BALLINGER, M. J.; BENTE, D. A.; BUCHMEIER, M. J. Taxonomy of the order Bunyavirales: second update 2018. Archives of Virology, v. 163 , n. 8 , p. $1-15,2019$. DOI: $10.1007 / \mathrm{s} 00705-018-$ $3843-5$

MICHELOTTO, M. D.; GODOY, I. J.; PIROTTA, M. Z.; SANTOS, J. F. dos; FINOTO, E. L.; FÁVERO, A. P. Resistance to thrips (Enneothrips flavens) in wild and amphidiploid Arachis species. PLoS One, v. 12, n. 5, p. e0176811, 2017. DOI: 10.1371/journal.pone.0176811

MiChELOTTO, M. D.; GODOY, I. J.; FÁVERO, A. 
P.; CARREGA, W. C.; FINOTO, E. L. Occurrence of Enneothrips flavens Moulton and Stegasta bosquella (Chambers) and its effects on agronomic traits of wild Arachis accessions. Bioscience Journal, v. 29, n. 1, p. 115-124, 2013.

NAGATA, T; ALMEIDA, A. C. L; RESENDE, R. O.; ÁVILA, A. C. The competence of four thrips species to transmit and replicate four tospoviruses. Plant Pathology, v. 53 , n. 2, p. 136-140, 2004. DOI: 10.1111/j.00320862.2004.00984.x

NAGATA, T.; RESENDE, R. O.; INOUE-NAGATA, A. K.; ÁVILA, A. C. The fluctuation specificity and efficiency of Tomato spotted wilt virus by Frankliniella schultzei. Fitopatologia Brasileira, v. 32, n. 5, p. 439, 2007. DOI: $10.1590 / \mathrm{S} 0100-41582007000500012$

NASCIMENTO, L. C. D.; PENSUK, V.; COSTA, N. P. D.; ASSIS FILHO, F. M. D.; PIO-RIBEIRO, G.; DEOM, C. M.; SHERWOOD, J. Evaluation of peanut genotypes for resistance to Tomato spotted wilt virus by mechanical and thrips inoculation. Pesquisa Agropecuária Brasileira, v. 41, n. 6, p. 937-942, 2006. DOI: 10.1590/ S0100-204X2006000600006

PAPPU, H. R.; JONES, R. A. C.; JAIN, R. K. Global status of tospovirus epidemics in diverse cropping systems: successes achieved and challenges ahead. Virus Research, v. 141, n. 2, p. 219-236, 2009. DOI: 0.1016/j. virusres.2009.01.009

REIS, L. N. A.; PANTOJA, M. B.; ANDRADE, G. P.; PIORIBEIRO, G.; GODOY, I. J.; RESENDE, R. O.; BLAWID, R.; MELO, F. L.; SOUZA, C. A.; CARVALHO, R. C. P. Detecção de isolados virais em amendoim através de análise metagenômica. In: CONGRESSO BRASILEIRO DE FITOPATOlOGIA, 48., São Pedro, 2015. Anais... Brasília, DF: Sociedade Brasileira de Fitopatologia, 2015. 1 CD-ROM.

RELEVANTE, C. A.; CHEEWACHAIWIT, S.; CHUAPONG, J.; STRATONGJUN, M.; SALUTAN, V. E.; PETERS, D.; BALATERO, C. H.; HOOP, S. J. Emerging new Poleroviruses and Tospoviruses affecting vegetables in Asia and breeding for resistance. Food and Fertilizer Technology Center. 2012. 12 p.
RILEY, D. G.; JOSEPH, S. V.; SRINIVASAN, R.; DIFFIE, S. Thrips vectors of Tospoviruses. Journal of Integrated Pest Management, v. 2, n. 1, p. 1-10, 2011. DOI: 10.1603/IPM10020

SINGH, A. B.; SRIVATAVA, S. K. Status and control strategy of peanut bud necrosis disease in Uttar Pradesh. In: SINGH, A. B.; SRIVATAVA, S. K. Recent studies on peanut bud necrosis disease: proceedings of a meeting of international crop research institute for semi-arid tropics (ICRISAT) Asia center, India, 1995. p. 65-68.

SOUZA-DIAS, J.A.C.; MORAES,A.R.; COLARICCIO, A.; CHAGAS, C. M.; GODOY, I. J.; MORAES, S. Presença de Tomato chlorotic spot virus na cultura do amendoim no Estado de São Paulo: observações preliminares e hipóteses para sua importância potencial. In: CONGRESSO PAULISTA DE FITOPATOLOGIA, 38., São Paulo, 2005. Anais... São Paulo: UNESP/FCA, 2005. p. S.59.

TURINA, M.; KORMELINK, R.; RESENDE, R. O. Resistance to Tospoviruses in vegetable crops: epidemiological and molecular aspects. Annual Review of Phytopathology, v. 54, n. 1, p. 347-371, 2016. DOI: 10.1146/annurev-phyto-080615-095843

UNITED STATES DEPARTMENT OF AGRICULTURE

- USDA, Foreign Agricultural Service. World Agricultural Production. 2018. Circular Series, January 2018. Available at: https://apps.fas.usda.gov/ psdonline/ circulars/production.pdf. Access at: 25 jan. 2018.

VERWOERD, C.; DEKKER, B. M.; HOECKEMA, A. A small-scale procedure for the rapid isolation of plant RNAs. Nucleic Acids Research, v. 17, n. 6, p. 2362, 1989. DOI: $10.1093 /$ nar/17.6.2362

WEBSTER, C. G.; FRANTZ, G.; REITZ, S. R.; FUNDERBURK, J. E.; MELLINGER, H. C.; MCAVOY, E.; TURECHEK, W. W.; MARSHALL, S. H.; TANTIWANICH, Y.; MCGRATH, M. T.; DAUGHTREY, M. L.; ADKINS, S. Emergence of Groundnut ringspot virus and Tomato chlorotic spot virus in vegetables in Florida and the Southeastern United States. Phytopathology, v. 105, n. 3, p. 388-398, 2015. DOI: 10.1094/PHYTO-06-14-0172-R 
